\title{
A Study on the Competitiveness Strengthening Plan of Industry: A Case from Korean ICT Parts Industry
}

\author{
${ }^{l}$ Moonkoo Kim, ${ }^{2}$ JongHyun Park, ${ }^{3}$ JongHyun Paik \\ 1, First Author ETRI, mkkim@etri.re.kr \\ *2,Corresponding Author ETRI, stephanos@etri.re.kr \\ ${ }^{3}$ KSA, jhpaik@ksa.or.kr
}

\begin{abstract}
In Korea the ICT parts industry has firmly established its position as a major contributor to the national economy based on increased exports and an improved trade balance. However, the Korean ICT materials and parts industry has stagnated in recent years due to heavy dependence on just a few products such as semiconductors and displays, intensifying global competition, a growing dependence on international trade, the nation's small business-centered industrial structure, etc. As such, this paper intends to study the government's policy of fostering the Korean ICT parts industry, as well as the industry's current situation, external competitiveness, and current problems, in order to propose industrial promotion measures to help Korean ICT parts industry attain global competiveness.
\end{abstract}

Keywords - ICT, Parts, Industrial Competitiveness

\section{INTRODUCTION}

The materials and parts industry is the foundation of the manufacturing industry and the basic industry of the national economy, as it is the key industry in determining the performance, quality and cost competitiveness of finished products. More specifically, as final product manufacturing and production capability has been standardized worldwide, the materials and parts industry is becoming increasingly important [1].

Since the early 2000's, Korean materials and parts industry has become a major driver of national economic development by greatly contributing to the export and trade balance, as its rapid growth - based on the global best level ICT technical capability - has continuously expanded the market size and the portion of materials and parts in manufacturing industries.

However, Korean ICT materials and parts industry has stagnated in recent years due to its heavy reliance on a few products such as semiconductors and displays, deepening global competition, growing dependence on international trade, its small business-centered industrial structure, and so forth.

As such, this paper intends to study the government policy of fostering the Korean ICT parts industry, as well as the industry's current situation, external competitiveness, and current problems, in order to propose industrial promotion measures to help Korean ICT parts industry attain global competiveness.

\section{Status AND Policy OF ICT PARTs Industry IN KOREA}

The Korean government has been steadily implementing policies aimed at boosting the growth of the ICT parts industry. The Ministry of Knowledge Economy announced its 'Future Vision 2020 for the Materials and Parts Industry' in October 2011 as the policy for growth of the materials and parts industry [2]. The plan includes the policy direction for enabling the Korean materials and parts industry to break away from the catch-up strategy of the past and transform it into an industrial structure akin to that of other advanced countries.

The Ministry of Industry, Commerce and Energy reported in 2013 the policy to foster the SW-convergent parts industry in a bid to advance the structure of the main industries [3]. The Ministry also proposed the implementation of the 'First-Mover Development Strategy of Material and Part' for strategic materials and SW-convergent parts to secure original technologies and lead the future markets.

Although Korean ICT parts industry has experienced rapid growth since the early 2000's, it has experienced stalled growth in terms of production, exports, imports and the trade balance since 2010, as shown in Table 1.

TABLE 1. Production, EMPloyment AND Trade TREND OF KorEAN ICT PARTS INDUSTRY

\begin{tabular}{c|c|c|c|c|c|c}
\hline Type & Unit & 2008 & 2009 & 2010 & 2011 & 2012 \\
\hline Production & KRW 1 billion & $108,958.7$ & $122,408.1$ & $174,430.1$ & $172,110.1$ & $176,931.8$ \\
\hline Employment & 10,000 people & 22.8 & 23.4 & 25.3 & 28.2 & - \\
\hline Exports & USD million & $63,713.5$ & $62,716.2$ & $91,301.7$ & $89,133.7$ & $91,228.7$ \\
\hline Imports & USD million & $43,508.9$ & $37,344.1$ & $44,363.2$ & $46,591.7$ & $46,678.9$ \\
\hline Trade balance & USD million & $20,204.6$ & $25,372.1$ & $46,938.5$ & $42,542.0$ & $44,549.8$ \\
\hline
\end{tabular}

Sources: [6][7][9]

For the past five years, the portion occupied by semiconductors and flat displays in Korean ICT parts industry has been above $80 \%$ in terms of production, exports and imports, thus indicating a heavy dependence on just a few items. As the trade balance of Korean ICT parts industry, excluding semiconductors and displays, is negative or almost negative, there is a need to diversify the product lineup. 
TABLE 2. SHARE OF KOREAN ICT PARTS INDUSTRY OCCUPIED BY SEMICONDUCTORS AND FLAT DISPLAYS

\begin{tabular}{c|c|c|c|c|c|c}
\hline & Product & 2008 & 2009 & 2010 & 2011 & 2012 \\
\hline \multirow{3}{*}{ Production } & Semiconductor & $31.5 \%$ & $33.7 \%$ & $35.1 \%$ & $35.6 \%$ & $34.7 \%$ \\
\cline { 2 - 7 } & Flat Display & $48.9 \%$ & $48.4 \%$ & $50.0 \%$ & $47.6 \%$ & $46.6 \%$ \\
\cline { 2 - 7 } & Subtotal & $80.4 \%$ & $82.1 \%$ & $85.2 \%$ & $83.2 \%$ & $81.3 \%$ \\
\hline \multirow{3}{*}{ Export } & Semiconductor & $51.5 \%$ & $49.5 \%$ & $55.5 \%$ & $56.3 \%$ & $55.3 \%$ \\
\cline { 2 - 7 } & Flat Display & $40.3 \%$ & $42.3 \%$ & $37.0 \%$ & $35.2 \%$ & $35.0 \%$ \\
\cline { 2 - 7 } & Subtotal & $91.8 \%$ & $91.8 \%$ & $92.5 \%$ & $91.5 \%$ & $90.3 \%$ \\
\hline \multirow{3}{*}{ Import } & Semiconductor & $73.6 \%$ & $71.3 \%$ & $70.2 \%$ & $69.7 \%$ & $69.1 \%$ \\
\cline { 2 - 7 } & Flat Display & $12.2 \%$ & $14.3 \%$ & $14.8 \%$ & $14.4 \%$ & $13.9 \%$ \\
\cline { 2 - 7 } & Subtotal & $85.8 \%$ & $85.6 \%$ & $85.0 \%$ & $84.1 \%$ & $82.9 \%$ \\
\hline
\end{tabular}

Sources: [7][9]

Korean ICT parts industry suffers from low profitability and consists mostly of small companies. Although the revenues of the top five companies in the ICT parts industry have been growing significantly year after year, the rate of operating profit is less than $10 \%$. As a matter of fact, the rate of operating profit of Korean top five ICT parts manufacturers decreased from $7.6 \%$ in 2007 to $5.3 \%$ in 2011 .

\section{Current Competitiveness And Problems of KOREAN ICT PARTS INDUSTRY}

Korean ICT parts industry is facing difficulties in terms of its global competitiveness due to its heavy dependence on international trade, the continuing competitive gap with Japan, and heavy competition with China.

Although the traditional dependence on Japan for parts has improved somewhat, there is still a regional risk as the dependence on China for trade has greatly increased [8]. Korean dependence on international trade is still very high, as shown by the fact that the portion of imports from Japan was $17.0 \%$ in 2007 and $12.4 \%$ in 2011, whereas the portion of exports to China was $30.0 \%$ in 2007 and $46.2 \%$ in 2011 and the portion of imports from China was $25.2 \%$ in 2007 and $31.4 \%$ in 2011.

As China's global market share in the ICT parts industry has increased significantly, the competition between Korea and China is also increasing [4][5]. In 2011, China was ranked first in the world with a $35.4 \%$ share of the global ICT parts market, while Korea was ranked second with just $10.3 \%$. As China's high cost competitiveness and technological competitiveness have been expanded somewhat, heated competition with Korea in the ICT parts industry is expected. When the export similarity index (ESI) between two countries approaches 1, it means the perfect competition. As ESI between Korea and China rose from 0.346 in 2000 to 0.685 in 2009, unlimited competition for market leadership in the global ICT parts industry is being carried out.

Korean ICT parts industry lacks key original technologies. In particular, the domestic part content of major ICT devices such as WCDMA mobile phones, mobile communication repeaters, RFID and set-top boxes is a mere 50\%.

The Korean ICT parts industry also lacks a favourable environment for the growth of small ICT companies. The growth foundation of small domestic companies is being steadily weakened due to an increase in the uses built-in parts and overseas outsourcing by large companies as well as the concentration of finished products among a few companies. The main domestic parts manufacturers depend on Samsung and Apple for 50 70\% of their revenues, which weakens the bargaining power of small parts manufacturers and eventually deprives them of the opportunity to grow on their own.

Korean small parts manufacturers are also faced with the urgent problem of stagnant growth due to their inadequate growth capability. Small Korean parts manufacturers, including manufacturers of electronic parts, experience stalled revenues at a specific point (i.e. revenue of KRW 10 billion 50 billion) in the growth curve. According to the Ministry of Knowledge Economy (2011), the reasons for the stagnant growth among small parts manufacturers include their lack of original technologies, weak quality competitiveness, difficulty in securing overseas sales channels, and shortage of outstanding human resources [2].

\section{IMPLICATIONS: COMPETITIVENESS STRENGTHENING PLAN OF KOREAN ICT PARTS INDUSTRY}

It intends to propose measures aimed at strengthening the competitiveness of the Korean ICT parts industry to help it secure a competitive edge in the global markets.

Firstly, it is required to increase the proportion of domestic content and breaking away from technology dependence on other advanced countries by securing original technologies for key ICT parts. It is necessary to strengthen original technological capability in WCDMA mobile phones, mobile telecommunication repeaters, RFID, set-top boxes, etc. as these are areas in which Korea is vulnerable.

Secondly, it is required to strengthen the implementation of market leading R\&D in the ICT parts industry. In other words, it is necessary to expand investment in pioneering $R \& D$ on key ICT part technologies to lead the future world markets.

Third, it is required to expand R\&D through industry-academy-research cooperation on SW convergent parts to promote the convergence of industries and services.

Fourthly, it is required to foster small but strong ICT parts manufacturers armed with global competitiveness. To that end, it is necessary to establish a customized growth-supporting ecosystem to drive the growth of small ICT parts manufacturers.

Finally, test bed development and overseas business support should also be strengthened to improve the product competitiveness and expand the global position of small ICT companies.

\section{REFERENCES}

[1] Hyundai Research Institute, Change of International Competitiveness of Korean Material Industry and Implication, VIP Report for Sustainable Growth, 2013.

[2] Ministry of Knowledge Economy, Material and Part Future Vision 2020, 2011 
[3] Ministry of Industry, Commerce and Energy, 2013 Business Report: Establishment of Creative Economic Ecosystem and Fostering of Global Specialized Company, 2013

[4] Samsung Economic Research Institute, Emergence of Chinese Part, Material and Equipment and Its Impact, 2012.

[5] Samsung Economic Research Institute, Study of Competitiveness and Ecosystem of Chinese Part, Material, Equipment and SW Industries, 2013.

[6] Korea Institute for Industrial Economics \& Trade (http://www.kiet.re.kr)

[7] National IT Industry Promotion Agency (http://www.nipa.kr)

[8] Korea International Trade Association (http://www.kita.net)

[9] Korea Electronics Association (http://www.gokea.org)

[10] Electronics and Telecommunications Research Institute (http://www.etri.re.kr)

[11] Korea Evaluation Institute of Industrial Technology (http://www.keit.re.kr) 